\title{
The Political ECONOMY OF INFORMATION EXCHANGE
}

(Politics and Property Rights in the Development and Use of Interorganizational Information Systems)

\section{NAME AND AFFILIATION OF THE AUTHOR:}

Vincent M.F. Homburg

Erasmus University Rotterdam

Faculty of Social Sciences

Center for Public Management

PO Box 1738

NL3000DR Rotterdam

The Netherlands

E-mail: homburg@fsw.eur.nl.

\section{BRIEF BIOSTATEMENT}

Vincent Homburg is Assistant Professor at Erasmus University Rotterdam, Center for Public Management. He has studied Public Administration and Policy Science (Twente University, the Netherlands) and received his Ph.D in Management and Organization Science in 1999 (Groningen University, the Netherlands). His research interests include information management and interorganizational relations, especially in the public sector. Vincent Homburg can be reached by e-mail:

homburg@fsw.eur.nl. 


\section{AbSTRACT (99 WORDS)}

Interorganizational information systems are information systems that cross organizational boundaries. Information managers and system developers often assume that the more integrated these information systems are, the more successful the system will be. Such an assumption is indeed intuitively appealing, and, from a technological standpoint, readily understandable. In practice, development and use of integrated information systems that cross organizational boundaries often result in confusing power struggles, politicking and sometimes manifest sabotage. Based on economic and political organization theory, this article concludes that data ownership and incentives, rather than integration, are of vital importance for the success of interorganizational information systems. 


\section{INTRODUCTION}

Recent trends like e-commerce, e-business and e-government challenge organizations to use information- and communication technologies to exchange knowledge and information and to collaborate with other organizations. By applying telecommunication networks, it is possible for organizations to open up their processes to suppliers, customers, and other business partners (Bakos and Nault, 1997).

Examples of such forms of electronic collaboration are to be found in the automotive industry (Reekers and Smithson, 1996), banking and insurance sector (Toppen, 1999), logistics (Wierda, 1991; Kreuwels, 1994), health care (Beynon-Davies, 1994) and penal law enforcement (Grijpink, 1997; Bellamy, 1998).

The information systems that are used to exchange information across organizational boundaries are often referred to as interorganizational information systems (Bakos, 1991), by means of which so-called extended enterprises emerge (Konsynski, 1993). Very often, there is an assumption in information management theory that the more integrated the interorganizational information system is, the more successful the collaboration between the participating organizations will be (Benjamin, de Long and Scott Morton, 1990; Scott Morton, 1991; Cunningham and Tynan, 1993). Integration can be defined as the standardization of data definitions and data structures through the use of a common conceptual scheme across a collection of data sources (Goodhue, Wybo and Kirsch, 1992). Konsynski and McFarlan state that "information has to be packaged for all partners by all partners, which requires the joint design of data definitions, formats, relationships and search patterns" (1990, p. 119). Furthermore, Huang (1998) hypothesizes that the greatest benefits from interorganizational information systems are obtained when integration of computer applications is achieved over a network of organizations. A typical form of an integrated interorganizational information system is a centralized data base management system containing all the unequivocal, relevant data of the organizations participating in the network. However, integration can also be achieved using a number of dislocated database management systems whose operations are tightly coordinated through a common architecture.

An example of an integrated interorganizational information system is TransLease (Allen, Colligan, Finnie and Kern, 1999), an electronic commerce system owned by Cap Gemini and used by a thousand British repair agents working for seven vehicle leasing and contract hire companies. TransLease uses standardized data formats throughout the network (which also enshrine the 'rules of trade') as the backbone of the system, in order to simplify the processing of auditing invoices.

Empirical evidence shows that the reality of interorganizational information systems is not as easy and profitable as the optimistic ICT advocates would lead us to believe. In practice, the question which data model is to be used often gives rise to organizational-political struggle and ownership disputes, and shows that the development and use of interorganizational information systems are complex and intriguing processes in which political and economic forces play a role (Webster, 1995; Kumar and van Dissel, 1996; see also Davenport, Eccles and Prusak, 1992; Knights and Murray, 1992; Elg and Johansson, 1997). Obviously, interorganizational 
information systems needs to be understood as a manifestation of interorganizational relationships as well as from a technological standpoint.

For instance, in the example of TransLease mentioned above, actual use of the system was far below expectations. An evaluation showed that the TransLease system did not provide the envisaged mutual benefits to its participants: "[a] dominant theme for repair agent complaints was their perception of an 'unfair' balance of power, which meant they felt that lease companies would tie them into a system that would reinforce and amplify existing power structures" (Allen, Colligan, Finnie and Kern, 1999, p. 10).

This kind of case studies have inspired academics and practitioners to question the dominant and popular ICT visions and to ask how interorganizational information systems get along with the problems of data modeling and data maintenance and whether a maximum of integration of computer systems across organizational boundaries is possible at all, and more importantly, really to be strived for from a management point of view (Kubicek, 1995).

In fact, there nowadays are initiatives where interorganizational information systems are designed with the explicit notion to preserve the participating organizations' autonomy as much as possible. In the Dutch social security sector, a complex network of public, public-private and private organizations, operational data on clients is not registered in a central database but is dispersed over a conglomerate of decentralized databases, connected through a separately-owned referral index (Homburg, 1999). The theoretical underpinnings of these interorganizational information systems, however, are far from developed. Therefore, in this article, the emergence of organizationalpolitical struggle and ownership disputes in relation to interorganizational information systems is analyzed using economic and political organization theory and these theoretical insights are confronted with data from a case study of the development of interorganizational information systems in the Dutch research and development sector (comprising of universities and private research institutes). The outcomes of this study are especially relevant for information-intensive industries (banking and insurances, government, research \& development) in which increasingly, information and communication technologies are used to share information and knowledge.

The structure of this article is as follows. In section two, interorganizational information systems are described as information resources or information assets and various ownership structures of interorganizational information systems (and thus, as we will demonstrate, various levels of integration) will be described using political and economic organization theory. The third section provides a case studies of the development of interorganizational information systems in the Dutch research and development community. In the fourth and final section, conclusions are drawn, the limitations of this study are discussed and implications for research and practice of interorganizational information systems are stated.

\section{AN ECONOMIC AND POLITICAL ViEW ON INTERORGANIZATIONAL INFORMATION SYSTEMS}

\section{INTRODUCTION}

In general, integration of information systems has much intuitive appeal from a technical point of view, as inconsistent data semantics (e.g., different definitions of performance criteria, product coding schemes and vendor purchase data) may 
seriously obstruct workflows and day-to-day business operations in networks of cooperating organizations. However, even in relatively unitary organizations that were aware of the problems associated with inconsistent data semantics and had attempted data standardization, integration failed or the organization experienced major difficulties (Goodhue, Quillard and Rockart, 1988; Goodhue, Kirsch, Quillard and Wybo, 1992; Wybo and Goodhue, 1995; Shanks, 1997), for example because 'unwilling' local managers refused to give up control over information systems.

\section{A Political VIEW ON INTERORGANIZATIONAL INFORMATION SYSTEMS}

A political view (Davenport, Eccles and Prusak, 1992; Elg and Johansson, 1997) sheds some light on the background of the struggle surrounding interorganizational information systems (Webster, 1995; Holland, 1995; Klein, 1996; Kumar and van Dissel, 1996; Bensaou, 1997). In political organization theory, for example resource dependence theory (Pfeffer and Salancik, 1978; see also Levine and White, 1961; Aldrich, 1976), organizations inhibit a complex world, in which many of the resources needed to attain their goals (including information and knowledge, client referrals, money, legal authority, political legitimacy, people and equipment) are controlled by other organizations. This means that, in practice, focal organizations enter into interorganizational relations with partner organizations (for instance, by using interorganizational information systems) in order to gain access to external resources. However, in doing this, they may have to comply with arrangements that may not be designed to suit them. Information handling procedures, terms of use and also data models may not always be geared to their requirements. In such a context, standardization of data models is certainly not a zero-sum game. According to political organization theory, each organization strives to optimize its self-interest by (1) minimizing their dependence on other organizations and (2) maximizing the dependence of other organizations on themselves (Reekers and Smithson, 1996). Standardization can be used as a strategy by powerful organizations to deliberately affect the dependence between organizations in a favorable way to them (Elg and Johansson, 1997). As Webster (1995) notes, standardization is an intensely political and adversarial process, because only the large and powerful parties can afford to get heavily involved in the standards development process. Truly joint design therefore is possibly a utopian ideal. As the less powerful parties are assumed to avoid further resource dependence, it is clear why standardization of data models is often forcefully resisted, if not the interorganizational information systems are in practice sabotaged. An example of this kind of behavior is provided by Beynon-Davies (1994). This author describes an attempt to develop a generalized model of healthcare data to be used in the British National Health Service (NHS), which can be characterized as a network of semi-autonomous organizations. However, despite large efforts the data model was never actually implemented. Although the development of the data model was originally portrayed as a neutral and technocratic exercise, the participating organizations very actively opposed the data model because they felt that the data model and especially the operational and financial data encompassed in the model, once implemented, could be used as a basis of comparison between NHS bodies. According to the semi-autonomous NHS bodies, the data model to be used to facilitate the exchange of information within the network thus raised unforeseen, partly unintended and very fundamental questions about accountability within the network of cooperating organizations (in this case, the NHS, Beynon-Davies (1994)). This suggestion has been confirmed in other studies. In a case study of a large, 
diversified organization, Markus reported that there was a suspicion that standardization of data models was used to enhance control over relatively autonomous divisions for the reason of "ferreting out how the knaves were doing in the trenches" (1983, p. 437). In a study of the diffusion of electronic data interchange technologies, Webster identified situations in which powerful organizations “(...) unilaterally imposed their in-house computer systems or information handling procedures upon their trading partners, extending their own hardware systems into their supplier's premises, dictating product and inventory coding according to their own established in-house information systems, and dictating the type and frequency of data to be exchanged" (1995, p. 37). Obviously, the view that networks of organizations can be regarded as structures containing mutual as well as conflicting interests (Elg and Johansson, 1997) also applies to the development and use of interorganizational information systems (Reekers and Smithson (1996) and Bensaou (1997)).

Although political organization theory provides an explanation for the organizationpolitical struggle surrounding the development and use of interorganizational information systems, actors are usually less realistically depicted as aberrant managers or deviant technologists, focusing on political aspects, nurturing organizational autonomy and ignoring effectiveness and efficiency. The politicking in relation to interorganizational information systems, however, is capable of being understood in other ways, among other things in ways that also include aspects of efficiency. In order to show how a more sophisticated understanding could throw more light on the topics under investigation here, we discuss a body of knowledge complementary to political organization theory, namely economic organization theory (more specifically, property rights theory).

\section{AN ECONOMIC VIEW ON INTERORGANIZATIONAL INFORMATION SYSTEMS} Property rights theory (Pejovich and Furubotn, 1973; Grossman \& Hart, 1986; Hart and Moore, 1991) is an extension to standard neoclassical analysis. It provides an analysis of behavior of individuals with respect to assets (including information assets, Brynjolfsson (1994); Van Alstyne, Brynjolfsson and Madnick (1995); Bakos \& Nault (1997)), under the assumption of bounded rationality. Bounded rationality refers to the impossibility to formalize all kinds of behavior in contracts that encompasses all future contingencies. Hence, property rights theory is also referred to as incomplete contracts theory. If we regard interorganizational information systems as information assets, it is possible to analyze behavior with respect to these kind of information systems with property rights theory.

Property rights theory defines property rights as "(...) the sanctioned behavioral relations among men that arise from the existence of goods an that pertain to their use. These relations specify the norms of behavior with respect to goods that each and every person must observe in his daily interaction with other persons, or bear the cost of non-observance" (Furubotn and Pejovich, 1974, p. 3). Hart and Moore (1990) furthermore state that a property right ultimately is the owner's ability to exclude others from the use of his or her asset. More specifically, Furubotn and Pejovich discern three categories of property rights: usus, the right to use an asset, abusus, the right to reconstruct an asset, and usus fructus, the right to appropriate the returns from the asset. 
If we regard an information system as an information asset, we see that full ownership of these assets involves the right to use an information system, to modify it with quality-enhancing or cost-saving features, and to appropriate the benefits of these adaptations. As an owner may exert the usus fructus property right, it has intensive incentives to perform well.

One of the options an owner of an asset possesses is to allow others to use the assets in exchange for a compensation, specified in a contract between user and owner. In this situation property rights theory states that because of bounded rationality, there will always be 'incompleteness' of contracts, implying that there will always be residual rights not covered in a contract. The institution that allocates these residual rights of is ownership (Brynjolfsson, 1994) and hence, the owner is 'residual claimant'. This situation occurs when in a network of organizations, one organization fully owns a central database while other organizations use it (that is, look in the database and/or enter information into the database) and contribute in the costs of the system through a agreed-upon lease contract. Such a separation of ownership and actual use has important consequences for the behavior with respect to information assets. Think of an employee who is working with an interorganizational information system that requires some specific investments from his side, for example participation in an on-the-job quality improvement training program. Such an employee faces intensive incentives to participate in such a program because in the long run, he can bargain for benefits in the form of a higher wage, promotion, more leisure time, et cetera. If we take the situation in which the system is owned by another organization, the marginal value of the participation of the employee in the program can be expected to be divided among employee, his boss and the owner of the system (as, in the bargaining process, the owner can exert hold-up power by threatening to withhold the asset). If the system were largely owned by his own organization, he can expect to receive a larger part of the marginal value in the bargaining process. Here we see that, in the absence of possibilities to formalize complicated reward schemes in contracts (e.g., assuming bounded rationality), a separation of ownership and control mitigates incentives. Van Alstyne et al (1994) characterize this situation with the phrase 'rental cars are driven less carefully than cars driven by their owners'.

This situation is different in a number of specific situations, namely if one of the participants is indispensable or if assets are complementary. Complementary assets are assets that are useless when used separate but represent value when used in conjunction. In these cases, the individual employee working with the asset is better off if property rights are dispersed among less participants (for an elaborate explanation and formalization of these mechanisms, refer to Goodman and Hart (1986), Hart and Moore (1991), Van Alstyne, Brynjolfsson and Madnick (1994) and Bakos and Nault (1997)) and the situation is characterized by more incentives to perform well for all employees, managers and asset owners involved.

For the specific situation of interorganizational information systems, it is relevant that the 'integration' of interorganizational information system mentioned before confronts employees with an attenuation of property rights, and hence, their incentives to perform well are partly mitigated. According to Van Alstyne, Brynjolfsson and Madnick (1995), this mitigation of incentives results in subtle intangible costs of low effort which will eventually appear as distorted, missing, or unusable data. The line of reasoning can be summarized as follows: the more the sense of 'ownership' is diminished, the less intense incentives will be. Consequently, the level of investments 
in the interorganizational information system will typically be lower, which in its turn affects the functionality, profitability, and eventually the viability of the interorganizational information system (Bakos and Nault, 1997). Of course, this line of reasoning is only valid in the absence of indispensability and complementarity of assets. In these cases, incentives of participants are best served by concentrated ownership, favoring participants' chances in ex-post bargaining processes.

This property rights theory applied to information assets provides a line of reasoning and a view on human behavior possibly is a caricature (as political organization theory does), but perhaps not such an unrealistic one (Hart, 1995). And, combining economic organization theory and political organization theory (see the section below), it provides us with a conceptual framework which allows the understanding of the difficulties and especially politicking surrounding the development and use of interorganizational information systems.

\section{SUMMARY OF THE LINE OF REASONING}

In the introduction of this article, it has been mentioned that there is a widely held belief among system developers and information managers that the more integrated interorganizational information systems are, the larger the chance for success is. After reviewing both political organization theory and economic organization theory, it is clear that integration, defined as the standardization of data definitions and data structures through the use of a common conceptual scheme across a collection of data sources, also has a number of negative consequences.

First, according to political organization theory, standardization of data definitions and data standards may be geared to the requirements of some organizations participating in an interorganizational information system, but not necessarily to the requirements of all organizations. Integration, according to political organization theory, may be used to enshrine interorganizational control and interorganizational surveillance in information technology (Webster, 1995). This is supposed to be contrary to an organization's quest for autonomy.

Second, according to economic organization theory, standardization of data definitions and data standards can be conceived as a mitigation of property rights with respect to the information system. Participants are less inclined to invest in the system and to enhance the information system with cost-saving or quality-enhancing features, and eventually such a diminishment of incentives results in less profitable, less functional and even less viable interorganizational information systems. According to Van Alstyne, Brynjolfsson and Madnick (1995), a typical symptom of lack of incentives is poor data quality, resulting from underinvestment in human and technical capital.

In figure one, a political economy framework for the development and use of interorganizational information systems is presented. It assumes that if organizations want to preserve access to information resources, they want to avoid excessive resource dependence, underinvestment by any of the participating organizations' members, and unintended interorganizational surveillance and control. In order to do this, an appropriate ownership structure and configuration of the interorganizational information system (in terms of economic property rights) must be decided upon.

[[Figure one about here]] 
Following the line of reasoning set out in the previous sections, we hypothesize that in the absence of indispensability and complementarity of information assets, organizations will opt for dis-integrated interorganizational information systems were possible, ensuring to exert property rights with respect to the interorganizational information systems (or parts of these) they are using. If we take the archetypes of the centralized database and the decentralized database with the referral index, we expect that cooperating organizations will prefer decentralized systems over centralized databases, which are fully 'owned' by one organization in a network of organizations that are using the system. This property theory-line of reasoning, as well as a political view on information resources, thus contradicts the intuitive logic indicating that integration is a necessary precondition of the success of an interorganizational information system and warrants other options than integration of these information systems.

In order to investigate this hypothesis, in the following section, a case study is presented of exchange of information through an interorganizational information system in the Dutch research community. Before moving on to this case study, a brief note on research methods is appropriate. The case study employs a qualitative and diverse set of methods including interviews with information managers, system developers, administrators and users of information systems, observations and document analysis. Although this article draws principally from the case study presented here, it was also informed by two other case studies in the Dutch social security and fiscal policy sector that were undertaken in the course of a larger research project. Finally, we would like to remark that statistical generalization is of course not applicable here. The case study presented here shows to illustrate and analytically generalize novel theoretical ideas (at the cornerstones of information management theory, political organization theory and economic organization theory) that may be applied in varying contexts.

\section{CASE STUDY: THE DEVELOPMENT OF INTERORGANIZATIONAL INFORMATION SYSTEMS IN THE RESEARCH COMMUNITY IN THE NETHERLANDS}

\section{BACKGROUND OF THE FIELD AND IMPORTANT STAKEHOLDERS}

As an introduction to the case study of the development and use of the NOD and CombiFormat interorganizational initiatives, first the policy and organizational background of the network under investigation is presented. In the Netherlands, an organizational network exists that consists of publicly or partly publicly financed research institutes. Traditionally, the Ministry of Education, or, more specifically, the Directorate of Higher Education and Scientific Research, is an important player in the field, who financially supports the research institutes and universities. The universities cooperate and participate in an interest association, the Association of Universities in the Netherlands (VSNU). The Royal Dutch Academy of Sciences (KNAW) is the interest association of the other research institutes.

Since a couple of years, the funding of institutes has taken a course from a hierarchical system in the direction of a market-oriented system, in which institutes have a greater amount of autonomy. Administrators of research institutes concern themselves with their market share instead of lobbying government officials or predisposing the Minister in favor of their plans (Gazendam \& Homburg, 1996). Historically, the institutes were used to report (initially in paper form and later on in the form of 
information systems) to a central registration owned by the Ministry. This implied that the Ministry requested information from the universities and research institutes and that the universities supplied the Ministry with the requested information. In fact, these information relations were, during the last few decades, stated in an information policy.

In 1985, research administrators quite explicitly opposed this approach, probably inspired by the changes in legislation (especially the system of funding) that were announced in that year. In the years before 1985, the information was used against them in cutback operations and the institutes, especially the universities, feared that these cutback operations would continue, inspired by the information they supplied. During a discussion on information management organized by the interest association of the universities, an anonymous participant said: “(...) a couple of years ago, association measures were identified between input and output. Should we have the fox guard the chicken coup by means of automating our registrations?". In this case, the interest association of the Dutch universities presented its own information policy proposals, to be used in the network of universities, research institutes, and government organizations. In 1990, it stated a number of information management principles, including that "the information exchanged should match the information requirements of the institutes themselves" (VSNU, 1996, p. 5). Furthermore, the importance of exchange through formal reports is stressed and it is argued that the number of reports should be minimized. Finally, it is stated that " $(. .$.$) controllability$ has to be sought in simplification rather than in integration of overly complex information flows" (VSNU, 1996, p. 5) and it is stated that " $(. .$.$) there is no need for$ new, government-owned, centralized registrations" (VSNU, 1996, p. 5).

The 'Information Conference' of 1992 marked a change in the information management approach adopted for the exchange of information between research institutes and the Ministry of Education. The set of indicators used by the Ministry raised a lot of criticism. During the conference, the institutes agreed that they would be held accountable for their results based on a set of indicators, but they also managed to agree with the Ministry that the initiative for the formulation of these indicators would be primarily in the hands of the institutes and their associations (see also Bekkers, 1998). At the same time the institutes acknowledged that the Ministry needs this information. However, there is a problem about the desired level of aggregation of the information to be exchanged. Agreement was reached on an approach in which the information needs of the Ministry will more and more be satisfied by the use of indicators.

Another very important result of the conference was that it was stated the Ministry of Education acknowledged that the information to be exchanged was owned by the research institutes (Bekkers, 1998).

\section{DEVELOPMENT OF A RESEARCH INFORMATION SYSTEM}

A special topic in the exchange of information in the research community is the exchange of information on research activities. Registration of research activities was asked for in order to inform businesses, social organizations, international research organizations and government of the research projects that were being conducted by universities and research institutes. The importance of this kind of exposure of research activities, both nationally as well as internationally, is widely shared among the various participating organizations in the research community. 
In order to accomplish this kind of exposure of research activities, in 1988, the NBOI was founded (this organization was renamed NIWI in 1997), among other things in order to design and develop a National Research Database (NOD), which was also to be owned and maintained by this organization. The Ministry assumed that with the establishment of the NOD, with which the research institutes in principle had agreed, the universities were obliged to submit research information to the NOD. The VSNU on the other hand, assumed that an obligation existed only if there was not a single trace of doubt as to (1) the method of submission of information and (2) what organizations should eventually receive the information. In practice, the association wanted to postpone its commitment to the agreement until the results of the expected evaluation of the NOD were available and until its own investigation of the possibility of alternative approaches, in line with its own information policy statements, had been completed. The VSNU demanded complete freedom with respect to technical and organizational aspects, so that it is possible for them to align completely with their own information and management policies. In the mean time, there was a lot of quarrel over the question who should provide the research information and who should contribute to the costs of the NOD. The latter question proved to be especially important because the institutes felt they did not experience any benefits from the NOD. Furthermore, the universities stated that they "(...) are not fully convinced of the usefulness of the [NOD] (...). The academic institutes are apprehensive of putting research information, which is to be classified as 'strategic' and which consists of input and output data at specific aggregation levels, at the disposal of (potential) users without explicit permission. If it is not clear to what use the information is to be put, [the institutes] refuse to supply this information" (Ambtelijk Overleg Onderzoek, 1990, p. 3). Another participant stated that "(...) if the NOD is accessible unconditionally, government is, through the back door, allowed access to information that, given the position of government, has to be characterized as 'management information'. Seen from the point of view of the universities, the supply of such an amount of management information is not acceptable". In the proceedings of a discussion meeting, it is noted that there is a preference for a coordinating and referring function for the NIWI with respect to research information systems, and no need exists for a complete, central and uniform register with detailed information with respect to output of research activities.

At the same time, it is noted that there are in practice problems with the day-to-day use of the NOD. Furthermore, a problem faced in the NOD initiative is that of the fourteen universities, only eight have a contract with the database owner for electronic data interchange, and the filling of the database in general falls short of expectations (Wetenschappelijk Technische Raad, 1997).

In response to these developments, and, according to some stakeholders, out of sheer aggravation, the VSNU developed the CombiFormat data model, to be used as a basis for several research information systems, which are interconnected and separately owned by research institutes or groups of research institutes. In 1997, the CombiFormat was accepted and implemented by ten of the fourteen universities (Advantage, 1997), which had either developed a research information system (in Dutch: OZIS or OIS) themselves, or had bought an existing system which was developed by another research institute. Although the federation of OIS/OZIS systems technically resembled the NOD database (in terms of design methodology, database technology, et cetera), there was one crucial difference: the participating organizations 
were explicitly granted ownership of their OIS or OZIS systems, which, for instance, allowed them to adapt and modify the underlying data model, and, more importantly, allowed the research institutes (being owners) ultimately to exclude access to their data in case there was a suspicion of use which had not been agreed upon on beforehand (e.g. in contingencies which had not been agreed upon in interchange agreements or other contracts with other research institutes, universities, the Ministry, NBOI/NIWI, et cetera).

In the following period, two competing interorganizational information systems existed. However, nearly all stakeholders agreed that this situation of competing interorganizational information systems was not desirable and two expert opinions were asked for (Wetenschappelijk Technische Raad (1997) and consecutively, Advantage (1997)).

In the experts' reports, it is firstly noted that "if the parties involved do not succeed in increasing drastically the timeliness and coverage [of the NOD], it is not likely that a NOD-like structure will survive. And the former is a prerequisite for justifying the costs the NOD incurs" (Wetenschappelijk Technische Raad, 1997, p. 8). Furthermore, it is recommended to gather and enter data at the source as much as possible

(Wetenschappelijk Technische Raad, 1997). In both reports, the necessity of a central database is questioned. In the report of Wetenschappelijk Technische Raad (1997), it is stated that possibly, over time, searches on decentral databases could be a satisfying solution. In the Advantage report, the following is stated: "[a]n important point of reference is that the organizations involved are highly autonomous. (...) The choice of a specific approach therefore has to take these relationships and mutual interdependencies into account. Here, the relationships between institutes and between institutes and NIWI are at stake. A combined bottom-up/top-down approach, in which all participants are taken into account, is preferred. (...) An incremental approach is to be preferred over a waterfall-like approach. (...) It is furthermore important to notice that the relationship between NIWI and the institutes is not self-evident. This relationship will have to be nourished on the basis of mutual value-added" (1997, pp. 9-10).

In general, both expert consultations result in support for the CombiFormat initiative and the OIS/OZIS systems over the NOD database. After a initial period of polarization, both the VSNU, research institutes and universities as well as the NBOI/NIWI support the conclusions of the experts. Even the Board of the Royal Dutch Academy of Sciences, under whose heading the NBOI/NIWI formally operates, stated that it did not exclude the possibility that, over a certain period of time, the alternative of decentralized data storage would predominate. They noticed that the core of the report implies a changed role of the NOD, with a more important role for the decentralized input of data by the institutes who are responsible for the research activities.

Indeed the role of the NIWI changed from being a source of data (through the NOD), to an organization that focuses on quality assurance and the active (international) marketing of the research information owned by the research institutes and universities. Furthermore, the NOD itself as an information system is transferred from being a 'pure' data base to an information system with a variety of functions, of which the most important ones are the referral to OIS/OZIS system using a thesaurus of 
search terms and indices. This is in accordance with the participating organizations' preference for a coordinating and referring function for the NIWI.

\section{POLITICS AND PROPERTY RIGHTS OF NOD AND COMBIFORMAT}

The developments mentioned above, relating both of the tasks and mission of the NIWI organization, as well as with respect to the NOD information system, marks the trajectory for changes in the research community in the Netherlands. Parts of these changes have already been completed and other changes are yet to come. Important here is that all stakeholders agree that the centralized NOD system, fully owned by NIWI is not an option any more, and that the decentralized OIS/OZIS systems are a more viable option.

In terms of political and economic organization theory, a number of remarks can be made. First of all, in terms of political organization theory, at least the research institutes and universities saw the establishment of the NOD as a sign of deliberate power use. More specifically, their fear was that the NOD could be used to gather management information which could be used for other, strategic purposes, than merely registration of research information for national and international exposure of research activities. In terms of economic organization theory, to the participating institutes, the NOD represented an information asset which elicited few incentives to invest scarce time and energy in. In fact, the signs of underinvestment were present: the NOD suffered from poor data quality by the fact that (1) not all institutes participated in the NOD and (2) the data that had been registered was timely nor accurate, and thus data quality was very poor.

The initiative to develop an alternative interorganizational information system, undertaken by VSNU, can therefore not only be interpreted as a sign of "sheer aggravation' but also as an attempt to develop an information system with more intense incentives to register data on research projects and eventually, to expose activities, nationally and internationally (a goal that is adhered to by many if not all participating institutes).

It is noteworthy to emphasize here that the crucial difference between the NOD and the OIS/OZIS system was not so much the technology nor the level of standardization as such (the CombiFormat data model of course was a de facto standard). More likely, the difference has to be sought in the dispersion of property rights. In the OIS/OZIS information systems, participating institutes were explicitly granted the right to eventually adapt the data model to local needs, and, to ultimately be able to exclude others from access to the data bases should there be suspicion of power abuse. Given the fact that the participating institutes were granted a high level of autonomy, the OIS/OZIS information systems provided them with far more intensive incentives to perform well on their maintenance of registration of research projects than the centralized NOD system did.

\section{CONCLUSIONS AND DISCUSSION}

Following the lines of reasoning of political organization theory and economic organization theory, we have presented a conceptual framework of the exchange of information through interorganizational information systems. In this framework, avoidance of excessive resource dependence, incentives, underinvestment and unintended surveillance and control play an important role as ingredients of the decision-making process with respect to the ownership structure of the 
interorganizational information system. Furthermore, a hypothesis was formulated regarding the expected ownership structure to follow out of the decision-making process (in the specific conditions of no indispensable and no complementary information assets).

The case study illustrated the indeed very political and adversarial decision-making process with respect to an interorganizational information systems in the Dutch research community. In the decision making process, the influences of the notions of incentives, underinvestment and attempts to avoid surveillance and control were observable. Furthermore, the study showed how a first attempt to develop an interorganizational information system (that is, the NOD system) failed because its ownership structure did not match the characteristics of the network of organizations (in terms of autonomy of the participating institutes, incentives, et cetera). An initiative to set up an (initially competing) information system with a more decentralized structure (CombiFormat), however, eventually replaced the NOD as the interorganizational information system to be used in the research community to record and exchange information on research endeavors.

The study therefore illustrates how important power, surveillance and control, incentives, and property rights are in the development of interorganizational information systems. It is noticeable that the initially envisaged, integrated NOD system owned by NIWI in fact did not pass the evolutionary filter of efficiency and legitimacy in the network of organization and was replaced by an information system that was roughly based on the same kind of technology in terms of database technology, communication facilities, et cetera but yet had a completely different ownership structure. This supports the idea that ownership structure and the behavioral consequences of ownership are more important in explaining the success of an interorganizational information system than purely technical variables (like technical performance) do, and, support the hypothesis mentioned in our summary of the line of reasoning of economic and political organization theory.

Furthermore, it is noticeable that from the theoretical framework and from the case data, it shows how poor data quality is a result of lack of incentives and in fact underinvestment in technical and human capabilities to keep the interorganizational information system viable, and that this can be mitigated by attributing property rights to the users of the system. This line of reasoning contradicts the sometimes-heard recommendation that poor data quality is best encountered by enforcing uniform data standards.

From this article, it seems there is little support for the intuitively logic indicating that a maximum level of informational integration across organizational boundaries is preferable from a management point of view. Although some participants in the network of research institutes saw the CombiFormat initiative as a sign of sheer aggravation, its emergence is perfectly understandable bearing the conceptual framework in mind. In fact, a line of reasoning encompassing economic ánd political aspects assumes prominence not only in the case description as a whole, but also by the anecdotal empirical evidence briefly mentioned in this article. Of course, it should be stressed that the particular strategies employed by the organizations and actors in the network described in the case study are not suggested to be the most common or important ones more generally. Still, these strategies were encompassed in the framework and may well arise in comparable situations.

\section{REFERENCES}


Advantage (1997). Oplossingsplan voor de VSNU inzake het WTR advies. (Solution for the VSNU concerning the WTR report). Internal Report. Rozenburg: Advantage / Utrecht: VSNU.

Aldrich, H. (1976). Resource dependence and interorganizational relations: Local employment service officers and social services sector organizations. Administration and Society, 7(4), 419-454.

Allen, D., D. Colligan, A. Finnie, T. Kern (1999). Trust, Power and InterOrganisational Information Systems: the case of the electronic trading community TransLease. Unpublished Research Report. Rotterdam: Faculty of Business Administration.

Ambtelijk Overleg Onderzoek (1990). Notitie inzake het onderzoeks-informatiebeleid in het WO. (Report concerning academic research information policy). Internal report. Utrecht: VSNU.

Bakos, J.Y. (1991). Information Links and Electronic Marketplaces: Implications of Interorganizational Information Systems in Vertical Markets. Journal of Management Information Systems, 8(2), 31-52.

Bakos, J.Y. \& B. Nault (1997). Ownership and Investment in Electronic Networks. Information System Research, 8(4), 321-341.

Bekkers, V.J.J.M. (1998). New Forms of Steering and the Ambivalence of Transparency. In Public Administration in an Information Age (pp. 293-306). Amsterdam: IOS Press.

Bellamy, C. (1998). ICTs and Governance: Beyond Policy Networks? The Case of the Criminal Justice System. In Public Administration in an Information Age (pp. 293306). Amsterdam: IOS Press.

Benjamin, R.I., D.W. de Long \& M.S. Scott Morton. (1990). Electronic Data Interchange: How much competitive advantage? Long Range Planning, 23(1), 29-40.

Bensaou, M. (1997). Interorganizational Cooperation: The Role of Information Technology. An Empirical Comparison of US and Japanese Supplier Relations. Information System Research, 8(2), 107-124.

Beynon-Davies, P. (1994). Information management in the British National Health Service: The Pragmatics of Strategic Data Planning. International Journal of Information Management, 14(2), 84-94.

Brynjolfsson, E. (1994). Information Assets, Technology and Organization. Management Science, 40(12), 1645-1662.

Cunningham, C. \& C. Tynan (1993). Electronic Trading, Inter-organizational Systems and the Nature of Buyer-Seller Relationships: The Need for a Network Perspective. International Journal of Information Management. 13(1), 3-28. 
Davenport, T.H., R.G. Eccles \& L. Prusak (1992). Information Politics. Sloan Management Review, 34(1), 53-65.

Elg, U. \& U. Johansson (1997). Decision Making in Inter-firm Networks as a Political Process. Organization Studies, 18(3), 361-384.

Furubotn, E.G., S. Pejovich (1974). The Economic of Property Rights. Cambridge: Cambridge University Press.

Gazendam, H.W.M. \& V.M.F Homburg (1996). Emergence of Multi-Actor Systems: Aspects of Coordination, Legitimacy and Information Management. In: Proceedings of the COST A3 Conference 'Management and New Technologies' 22-24 June, Madrid.

Goodhue, D.L., L.J. Kirsch, J.A. Quillard \& M.D. Wybo (1992). Strategic Data Planning: Lessons from the Field. MIS Quarterly, 16(3), 11-34.

Goodhue, D.L., J.A. Quillard \& J.F. Rockart (1988). Managing The Data Resource: A Contingency Perspective. MIS Quarterly, 12(3), 373-391.

Goodhue, D.L., M.D. Wybo \& L.J. Kirsch (1992). The Impact of Data Integration on the Costs and Benefits of Information Systems. MIS Quarterly, 16(3), 293-311.

Grijpink, J.H.A.M.(1997) Keteninformatisering, met toepassing op de justitiële bedrijfsketen. (Value chain informatization, with application to the juridical supply chain). The Hague: SDU.

Grossman, S. \& O. Hart (1986). The Costs and Benefits of Ownership: A Theory of Vertical and Lateral Integration. Journal of Political Economy, 94(4), 691-719.

Hart, O. (1995). An Economists Perspective on the Theory of the Firm. In: O.E. Williamson (1995). Organization theory: From Chester Barnard to the Present and Beyond. Oxford: Oxford University Press.

Hart, O. \& J. Moore (1990). Property Rights and the Nature of the Firm. Journal of Poliical Economy, 98(6), 1119-1158.

Holland, C.P. (1995). Co-operative supply chain management: the impact of interorganizational systems. Journal of Strategic Information Systems, 4(2), 117-133.

Homburg, V.M.F. (1999). The Political Economy of Information Management (A Theoretical and Empirical Analysis of Decision Making regarding Interorganizational Information Systems). Capelle a/d IJssel: Labyrint Publication.

Huang, K. (1998). Organizational aspects of EDI: A norm-oriented approach. Enschede: Twente University. 
Klein, S. (1996). The configuration of inter-organisational relations. European Journal of Information Systems. 5(2), 92-102.

Knights, D. and F. Murray (1992). Politics and Pain in Managing Information Technology: A Case Study from Insurance. Organization Studies. 13(2), 211-228.

Konsynski, B.R. (1993). Strategic Control in the Extended Enterprise. IBM Systems Journal. 32(1), 111-142.

Konsynski, B.R. \& W.F. McFarlan (1990). Information Partnerships - Shared Data, Shared Scale. Harvard Business Review, 68(5), 114-120.

Kreuwels, C.M.A. (1994). Externe logistieke integratie en EDI - naar meerniveau afstemming tussen toeleverancier en afnemer. (External logistics integration and EDI; towards multilevel coordination between supplier and buyer). Deventer: Kluwer Bedrijfsinformatie.

Kubicek, H. (1995). The organisational gap in large-scale EDI systems. In COST A4: The social shaping of interorganizational IT systems and electronic data interchange. Proceedings of the PICT/COST A4. International Research Workshop (pp. 75-108). Luxembourg: Office for Official Publications of the European Communities.

Kumar, K. \& H.G. van Dissel (1996). Sustainable collaboration: managing conflict and collaboration in inter-organizational systems. MIS Quarterly, 20(3), 279-300.

Levine, S. \& P. White (1961). Exchange as a conceptual framework for the study of interorganizational relationships. Administrative Sciences Quarterly. 5(2), 583-601.

Merali, Y. \& P. McKiernan (1993). The strategic positioning of information systems in post-acquisition management. Journal of Strategic Information Systems 2(2), 105124.

Pfeffer, J. \& G. Salancik (1978). The external control of organizations. New York: Harper and Row.

Reekers, N. \& S. Smithson (1996). The role of EDI in inter-organizational coordination in the European automotive industry. European Journal of Information Systems, 5(2), 120-131.

Scott Morton, M.S. (ed.) (1991). The Corporation of the 1990s - Information Technology and Organizational Transformation. New York: Oxford University Press.

Shanks, G. (1997). The challenges of strategic data planning in practice: an interpretative case study. Journal of Strategic Information Systems, 6(1), 69-90.

Toppen, R. (1999). Improving the Performance of Electronic Business Networks. Rotterdam: Toppen. 
Tushman, M. (1977). A Political Approach to Organizations. A Review and Rationale. Academy of Management Review, 2(2), 206-216.

Van Alstyne, M., E. Brynjolfsson \& S. Madnick (1995). Why not one big database? Principles for data ownership. Decision Support Systems, 15(4), 267-284.

VSNU (1996). CIB-nota Informatiebeleid 1996. (CIB report Information Policy). Internal Report. Utrecht: VSNU.

Webster, J. (1995). Networks of collaboration of conflict? Electronic data interchange and power in the supply chain. Journal of Strategic Information Systems, 5(1), 31-42.

Wetenschappelijk Technische Raad (1997). De Nederlandse Onderzoeksdatabank Nieuwe Stijl. Systeem voor Lopend Onderzoek Informatie. (The New Style Dutch Research Database. A System for Information on Current Research). Internal Report. Utrecht: Wetenschappelijk Technische Raad.

Wierda, F.W. (1991). Developing Interorganizational Information Systems. Delft: Eburon.

Williamson, O.E. (1995). Organization theory: From Chester Barnard to the Present and Beyond. Oxford: Oxford University Press.

Wybo, M.D. \& D.L. Goodhue (1995). Using interdependence as a predictor of data standards. Theoretical and measurement issues. MIS Quarterly, 29(6), 317-329. 
[[Figure 1: Political Economy Framework]]

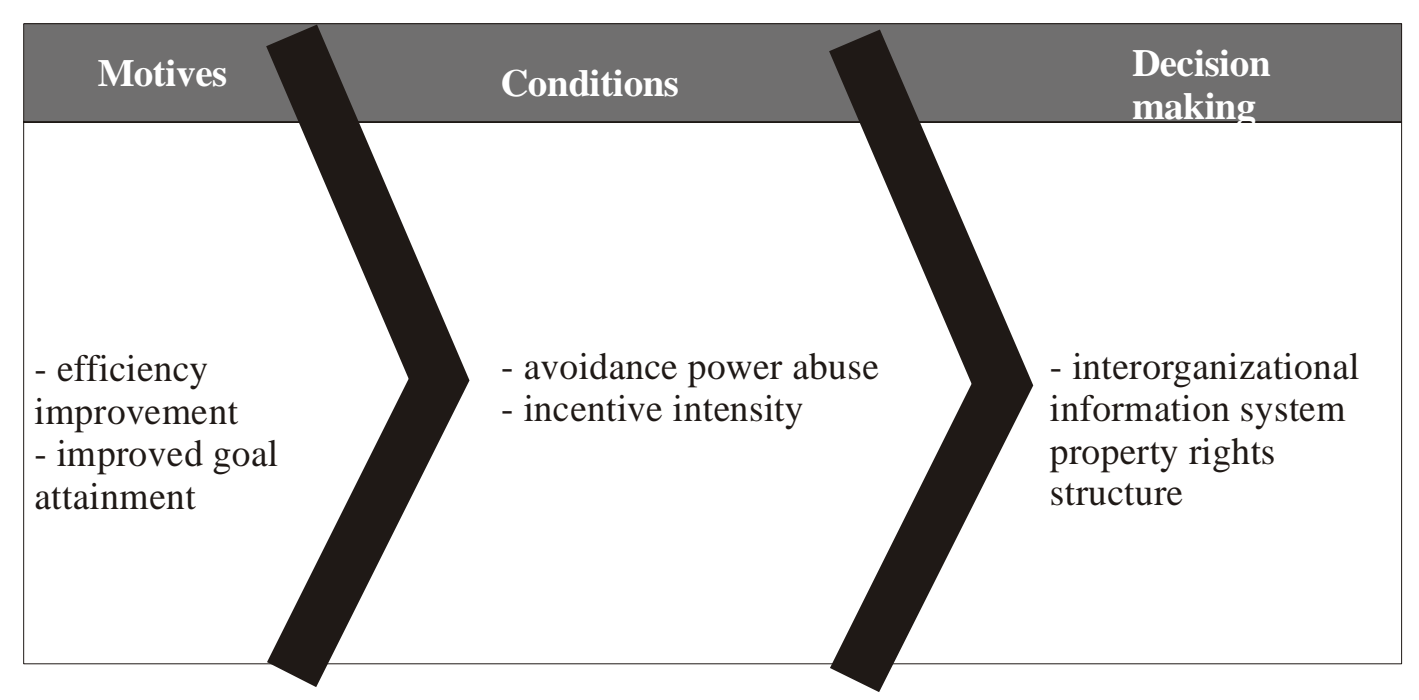

